\title{
AN ANALYSIS OF LONG TERM CATCH TRENDS IN MARINE FISHERY RESOURCES OF KARNATAKA STATE, INDIA
}

\author{
ADIGA, S. M. ${ }^{1}{ }^{*}$ - ANANTHAN, P. S. ${ }^{1}$ - DIVYA KUMARI, H. V. ${ }^{2}$ - MALLIKARJUN, H. ${ }^{3}$ \\ ${ }^{1}$ Central Institute of Fisheries Education \\ Deemed University- ICAR, 7 Bunglows, Versova, Andheri West, Mumbai- 400061, India \\ (phone: +91-872-2759-284) \\ ${ }^{2}$ Department of Aquaculture \\ College of Fisheries, Mangalore-575002, Karnataka, India \\ ${ }^{3}$ Inland Fisheries Unit \\ University of Agricultural science, Bangalore, Karnataka, India \\ *Corresponding author \\ e-mail: suresha1947@gmail.com \\ (Received $15^{\text {th }}$ Dec 2014; accepted $17^{\text {th }}$ Dec 2015)
}

\begin{abstract}
Marine fish production from capture fisheries in India has increased by about six folds during the past six decades. Therefore, monitoring the exploited marine fishery resources at regional level is very important for effective fisheries management for sustainability. In this regard, dynamic changes in Karnataka State's marine fisheries landings over the last five decades were examined after classifying them into 19 different resource groups. Decade wise Compound Growth Rate (CGR) and Coefficient of Variation (CV) of different resource groups were calculated. Most of the stocks classified as abundant and less abundant at national level fell under declining status in Karnataka State. The indicate that the state wise scenario is different from national scenario and thus understanding state wise marine fishery is important to formulate regulation and management measures.
\end{abstract}

Keywords: Compound Growth Rate, fishery resources, Karnataka fishery, stock status, sustainability

\section{Introduction}

Fisheries have rarely been sustainable (Pauly et al., 2002); many literatures around the globe describes the decline of fisheries worldwide (Casey and Myers, 1998; Pauly et al., 1998; Jackson et al., 2001; Mayers and Worm, 2003). FAO reported that $61.3 \%$ of the world's fish stocks are fully fished (FAO, 2014) and this scenario did not happen overnight (Jensen, 2002). It is the result of improvements in fishing technologies, overexploitation and mismanagement of resources over a period of time (Zeller and Pauly, 2005; Eagle and Thompson, 2003; Jensen, 2002; Bundy and Pauly, 2001; McManus et al., 1997; Caddy et al., 1998). Similarly, India is also not exempted from impending fisheries crisis. Marine fisheries in India are facing problems of excessive fishing pressure, over exploitation of majority of marine fisheries resources, reduced catch rates, catching juveniles and discards. Over the years, with the help of government schemes and supports, fishing has undergone drastic mechanization leading to imbalance in exploitation across the regions and among the resources. Karnataka, a state along the west coast of India has a coastline of around $300 \mathrm{~km}$ and a continental shelf area of 27000 sq. km. (GoI, 2012) with an exclusive economic zone of $87000 \mathrm{sq} . \mathrm{km}$. Marine fisheries play an important role in Karnataka's economy and forms an important source of consumption, employment and foreign exchange. Marine fish production in Karnataka during 2011 was 437000 tonnes (CMFRI, 2012) contributing around 9\% of 
India's total marine fish production. As of now more than 80 species are commercially harvested along the coastal Karnataka (Bhatta et al., 2003). Among these, sardine (Sardinella longiceps), mackerel (Rastrelliger kanagurta), threadfin bream, cephalopods, carangids, ribbonfish, stomatopods, lizardfish and penaeid prawns contribute primarily to the state fish landings. Production was dominated by mechanized fishing gears mainly trawlers and other gears like seines and gill nets. Exploitation of resources has undergone major changes with the introduction of mechanised boats and trawlers. As per latest estimates, there are about 2847 trawlers, 422 purse seiners, 200 gill netters, 7518 motorized and 2862 non motorized boats operating along the coastal Karnataka (CMFRI, 2010).

In recent years, growth in marine fish production has almost been stagnant. Fisheries have been affected by number of problems and issues with serious consequences on the availability and sustainability of fish. The resources are highly under stress (Dehadari and Yadava, 2004) as they have been exploited to their maximum (Shyam et al., 2010). Thus it is very important to assess the status of commercially important marine fishery resources to understand their trend over a period of time. No detailed long term catch trend analysis has been carried out in Karnataka, though changes on a yearly basis are recorded in Central Marine Fisheries Research Institute (CMFRI) data base. However, Mohamed et al., (1998) studied Karnataka State's marine fisheries during 1990-1995. Also, Bhat and Bhatta (2001) studied economic analysis of sustainability of marine fish production in Karnataka State. Observations on pelagic resource dominance pattern for the period 1961-2003 was done by Kuriakose and Mini (2006). Understanding the pattern and crucial milestones in landings over a period of time is sine qua non and would provide insights into the level of resource exploitation there by helping to promate appropriate management measures. Time series landings data on major resource groups gives a broad understanding on the status of the stock.

\section{Materials and Methods}

Data on Karnataka state's marine fish production for the last fifty years (1961-2010) were collected from CMFRI, Cochin. The marine species were classified into 19 groups. Compound Growth Rate (CGR) was estimated decade-wise for overall catch and total landings of both Karnataka and India during 1961-2010 and compared. CGR for different growth phases (1961-1975, 1976-1985, 1986-1995 and 1996-2010) was also estimated.Coefficient of Variation (CV) was calculated for each decade and the decadal mean catch were calculated to see trends over the period from 1961-2010. Decade wise percentage contribution of each group to total state landings was also estimated to identify the major fishery contributing to the states production over a period of time.

Decade-wise trend in marine fish landings and major developments in Karnataka's fishery have been summarized. Present status of different resources of the state were estimated based on the criteria proposed by Mohamed et al., (2010) by classifying resources into five groups viz., Abundant, less abundant, declining, depleted and collapsed as shown in Table 1. Percentage contribution of these five groups to average total catch for the last ten years (2001-2010) and for last three years (2008-2010) were calculated. 
Table 1. Criteria used for fish stock classification

\begin{tabular}{c|c}
\hline Stock classification & Recent average catch in historical maximum $(\%)$ \\
\hline Abundant & $>70$ \\
Less abundant & $50-69$ \\
Declining & $11-49$ \\
Depleted & $6-10$ \\
Collapsed & $<5$ \\
\hline
\end{tabular}

\section{Results}

\section{Total Marine fish landings of Karnataka, India: 1961-2010}

The average fish production in the country rose from 832000 tons in 1961-70 to 2738000 tons in 2001-2010. Correspondingly, fish production in Karnataka has touched 253000 tons in 2001-2010 from 67 thousand tons in 1961-1970 (Table 2). Karnataka's share in India's fish production grew gradually from $8.05 \%$ during 1960 s to $9.26 \%$ in 2001-10 with an average contribution of $8.51 \%$. State's decadal mean marine fish production had an increasing trend till 1980's, decreased during 1990's and improved during recent decades. The trend equations for both India and Karnataka's fish production are shown in Figure 1. Less variations in landings as indicated by CV were observed during 90's for both India and Karnataka. Decade wise CGR for India and Karnataka (Table 3) indicates a low growth trend in 1991-2000 compared to other decades. Inter year growth rate in India during all decades showed significant difference except in 1970's (t value=2.184), where in Karnataka, a significant diference was shown during 1960's, 1980's and 2001-10.

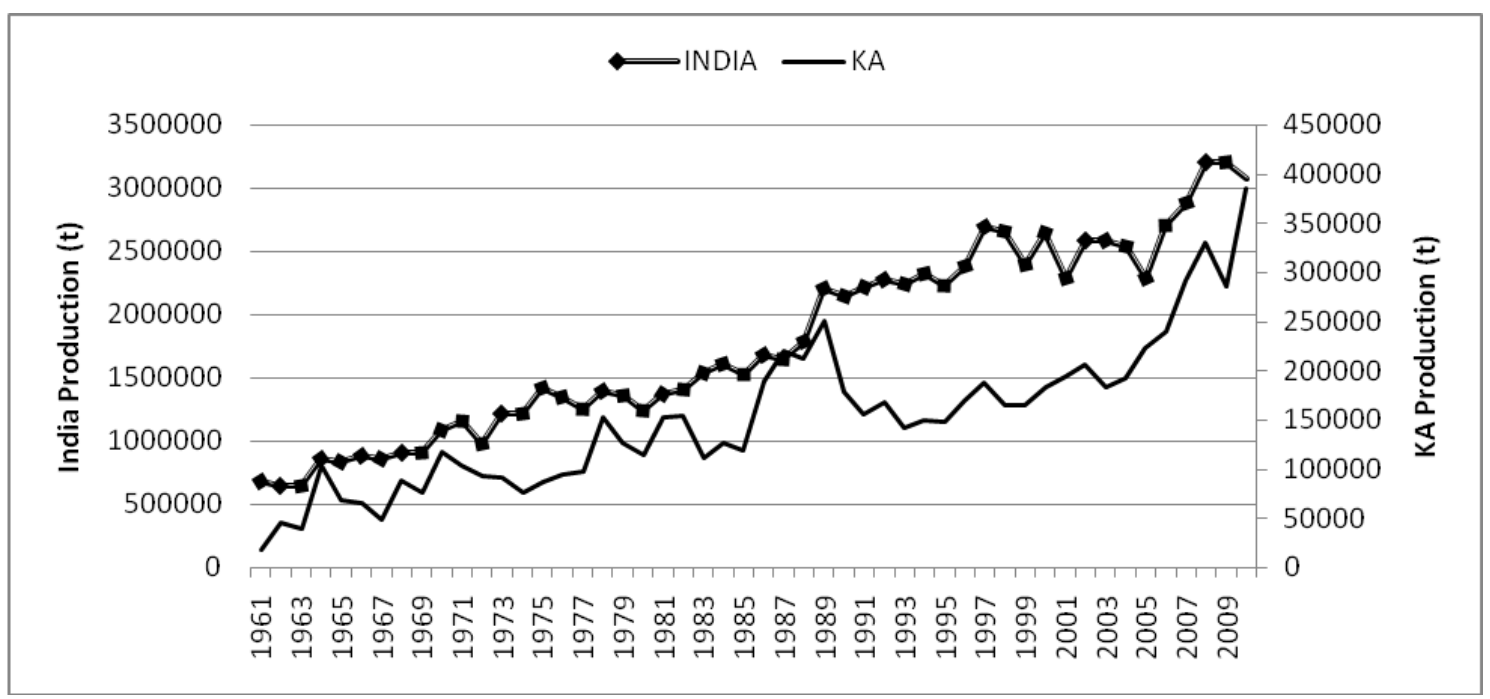

Figure 1. Trend in total annual marine fish landings (tons) in India and Karnataka from 1961 2010

Average mean catch, CV and CGR were estimated for different growth phases of Karnataka and compared with India (Tables $4 \& 5$ ). Highest average mean catch for the state $(227042$ t) and country (2678792 t) were observed during 1996-2000. Growth trend of Karnataka found to increase recently (5.54) compared to 1986-1995 phase (4.84). But growth in national scenario (1.64) is decreased when compared to 1986- 
1995 (3.84). In both state and national scenario,inter year growth rate was significantly varied from each other during all the decades (except in 1970's in Karnataka ( $t$ value= 0.967)).

Table 2. Decadal mean catch (tons) Coefficient of Variation (CV) for Indian and Karnataka marine fisheries

\begin{tabular}{l|c|c|c|c|c}
\hline Year & $\begin{array}{l}\text { Mean catch in } \\
\text { India (t) }\end{array}$ & $\begin{array}{l}\text { Mean catch in } \\
\text { Karnataka (t) }\end{array}$ & C.V India (\%) & $\begin{array}{l}\text { C.V } \\
\text { Karnataka } \\
(\%)\end{array}$ & $\begin{array}{l}\text { \% Karnataka } \\
\text { contribution } \\
\text { to India }\end{array}$ \\
\hline $1961-70$ & 832426 & 67048 & 15.62 & 43.11 & 8.05 \\
$1971-80$ & 1259624 & 103864 & 9.91 & 20.35 & 8.25 \\
$1981-90$ & 1692597 & 171700 & 15.84 & 25.87 & 10.14 \\
$1991-00$ & 2408687 & 163602 & 7.50 & 8.48 & 6.79 \\
$2001-10$ & 2738943 & 253608 & 11.85 & 25.28 & 9.26 \\
$1961-2010$ & 1786455 & 151964 & 41.39 & 49.19 & 8.51 \\
\hline
\end{tabular}

Table 3. Decade wise Compound growth rate (CGR) for India and Karnataka

\begin{tabular}{l|c|c|c|c}
\hline Year & CGR (India) & $\mathrm{t}$ value (India) & CGR (Karnataka) & t value (Karnataka) \\
\hline $1961-70$ & 5.15 & 5.952 & 14.37 & 2.917 \\
$1971-80$ & 2.26 & 2.184 & 4.02 & 2.057 \\
$1981-90$ & 5.00 & 6.861 & 6.30 & 2.47 \\
$1991-00$ & 2.04 & 3.588 & 1.70 & 1.954 \\
$2001-10$ & 3.55 & 4.417 & 7.99 & 6.262 \\
$1961-2010$ & 3.11 & 29.486 & 3.49 & 11.983 \\
\hline
\end{tabular}

Table 4. Mean catch (tons) Coefficient of Variation (CV) for Indian and Karnataka (KA) marine fisheries in different phases/ periods

\begin{tabular}{l|c|c|c|c|c}
\hline Year & $\begin{array}{l}\text { Mean catch } \\
\text { (India) in t }\end{array}$ & $\begin{array}{l}\text { Mean catch } \\
\text { (KA) in t }\end{array}$ & CV (India) & CV (KA) & $\begin{array}{l}\text { \% Karnataka } \\
\text { contribution to } \\
\text { India }\end{array}$ \\
\hline $1961-1975$ & 954194 & 74808 & 22.85 & 35.46 & 7.84 \\
$1976-1985$ & 1406816 & 125244 & 8.10 & 16.84 & 8.90 \\
$1986-1995$ & 2075982 & 181804 & 12.00 & 18.87 & 8.84 \\
$1996-2010$ & 2678792 & 227042 & 10.81 & 28.48 & 8.56 \\
\hline
\end{tabular}

Table 5. Compound growth rate (CGR) for India and Karnataka (KA) during different phases

\begin{tabular}{l|c|c|c|c}
\hline Year & CGR (India) & $\mathrm{t}$ value (India) & CGR (KA) & $\mathrm{t}$ value (KA) \\
\hline $1961-1975$ & 5.13 & 10.481 & 7.70 & 3.236 \\
$1976-1985$ & 2.17 & 3.342 & 1.94 & 0.967 \\
$1986-1995$ & 3.84 & 4.474 & -4.84 & -3.675 \\
$1996-2010$ & 1.64 & 3.164 & 5.54 & 7.328 \\
\hline
\end{tabular}

\section{Production during 1961-1970}

Pelagic fishery were dominant in Karnataka's marine landings during 1960's. As apparent from the data in Table 6, clupeids accounted for 53.34\% and mackerel contributes $22.48 \%$ to the state's total average landing. Indian oil sardine was the major species dominating the clupeid fishery. Contribution of demersal fishes to marine fish 
landings was meager compared to pelagic resources. Resources such as catfish (3.34\%), croakers $(2.78 \%)$, elasmobranchs $(2.12 \%)$, silverbellies $(1.87 \%)$ were dominating among demersal groups. Average mean catch of crustaceans was 2723 tons, which was about $4.06 \%$ of the state's total catch. All the groups witnessed higher variation in landings. Trends in growth (CGR) during the decade were high for the majority of groups except for croakers (-11.10), elasmobranchs (-1.60), perches (-7.80) and barracudas (-21.25). Inter year growth rate showed significant variation for crustaceans, catfish, carangids and half beak \& full beaks (Table 6 ).

Table 6. Mean fish catch (tons), CV, CGR and percent contribution of various major fish groups in Karnataka during 1961-1970

\begin{tabular}{l|c|c|c|c|c}
\hline Species & Mean catch $(\mathrm{t})$ & $\mathrm{C} . \mathrm{V}$ & CGR & $\mathrm{t}$ value & \% catch to total state landings \\
\hline Clupeids & 35763 & 67.54 & 24.46 & 2.093 & 53.34 \\
Mackerel & 15072 & 75.42 & 8.14 & 1.101 & 22.48 \\
Crustaceans & 2723 & 79.33 & 18.79 & 2.346 & 4.06 \\
Catfish & 2238 & 121.76 & 40.49 & 5.179 & 3.34 \\
Croakers & 1862 & 85.06 & -11.10 & -1.829 & 2.78 \\
Elasmobranchs & 1419 & 43.50 & -1.60 & -0.356 & 2.12 \\
Silverbellies & 1254 & 78.49 & 6.02 & 0.627 & 1.87 \\
Carangids & 794 & 55.56 & 19.34 & 4.279 & 1.18 \\
Pomfrets & 587 & 189.11 & 18.83 & 1.461 & 0.87 \\
Seer Fish & 499 & 80.65 & 17.01 & 2.318 & 0.74 \\
Flatfish & 453 & 56.37 & 6.45 & 1.137 & 0.68 \\
Whitefish & 271 & 55.47 & 11.46 & 1.254 & 0.40 \\
Ribbonfish & 239 & 73.62 & 9.08 & 0.743 & 0.36 \\
Perches & 165 & 53.82 & -7.80 & -1.231 & 0.25 \\
HB \& FB & 92 & 60.04 & 19.00 & 2.434 & 0.14 \\
Tunnies & 73 & 89.77 & 0.04 & 0.002 & 0.11 \\
Lizard fish & 16 & 136.53 & 25.70 & 1.248 & 0.02 \\
Molluscs & 11 & 153.24 & 24.58 & 1.237 & 0.02 \\
Barracudas & 7 & 107.30 & -21.25 & -2.142 & 0.01 \\
\hline
\end{tabular}

\section{Production during 1971-1980}

All the groups except half beak and full beaks showed increase in their landings which resulted in increased total state landings during 1971-1980 (Table 7). Major resources contributing during this decade were clupeids (35771 t), mackerel (31302 t), crustaceans $(7288 \mathrm{t})$, catfish (3967 t) and elasmobranchs (2498 t). Even though catch increased, the contribution of clupeids and mackerel to state's total landings was decreased by $11.24 \%$ compared to previous decade, which may be mainly due to improved landings by other groups. Though the mean catch increased, resources such as mackerel (-2.25), crustaceans (-3.52), elasmobranchs (-0.85), seer fish (-2.16), whitefish $(-10.63)$, and pomfrets $(-3.29)$ showed a negative trend in growth (CGR), which was due to high variation in landings especially during mid 70's (1974-1977). Only three resources such as clupeids, catfish and tunas showed significant difference in inter year growth rate. 
Table 7. Mean fish catch (tons), CV, CGR and percent contribution of various major fish groups in Karnataka state during 1971-1980

\begin{tabular}{l|c|c|c|c|c}
\hline Species & Mean catch & C.V & CGR & t value & \% catch to total state landings \\
\hline Clupeids & 35771 & 42.38 & 15.87 & 4.449 & 34.44 \\
Mackerel & 31302 & 51.57 & -2.25 & -0.334 & 30.14 \\
Crustaceans & 7288 & 43.31 & -3.52 & -0.665 & 7.02 \\
Catfish & 3967 & 58.94 & 15.99 & 3.393 & 3.82 \\
Elasmobranchs & 2498 & 35.48 & -0.85 & -0.212 & 2.41 \\
Silverbellies & 2431 & 55.39 & 12.22 & 1.914 & 2.34 \\
Croakers & 2306 & 35.00 & 7.76 & 1.806 & 2.22 \\
Seer Fish & 1685 & 30.15 & -2.16 & -0.561 & 1.62 \\
Carangids & 1315 & 92.31 & 10.82 & 1.267 & 1.27 \\
Flatfish & 1072 & 56.84 & 0.37 & 0.055 & 1.03 \\
Whitefish & 711 & 76.08 & -10.63 & -1.176 & 0.68 \\
Pomfrets & 674 & 76.81 & -3.29 & -0.396 & 0.65 \\
Tunnies & 586 & 76.60 & 22.70 & 2.796 & 0.56 \\
Molluscs & 581 & 161.54 & 51.48 & 1.78 & 0.56 \\
Ribbonfish & 565 & 76.28 & 14.61 & 1.688 & 0.54 \\
Perches & 473 & 95.22 & 17.25 & 1.614 & 0.46 \\
Lizardfish & 178 & 95.58 & 40.82 & 1.336 & 0.17 \\
Barracudas & 64 & 125.58 & 6.93 & 0.425 & 0.06 \\
HB \& FB & 54 & 87.53 & 20.28 & 1.878 & 0.05 \\
\hline
\end{tabular}

\section{Production during 1981-1990}

The combined landings of fish from Karnataka increased from $103864 \mathrm{t}$ in 19711980 to 171700 t during 1981-1990. Mean catch, CV, CGR and percentage contribution of major groups to state's total landings are shown in Table 8.

Table 8. Mean fish catch (tons), Coefficient of Variation (C.V.), Compound Growth Rate (CGR) and percent contribution of various major fish groups in Karnataka state during 1981-1990

\begin{tabular}{l|c|c|c|c|c}
\hline Species & Mean catch & C.V & CGR & t value & \% catch to total state landings \\
\hline Clupeids & 60319 & 19.33 & -1.07 & -0.452 & 35.13 \\
Mackerel & 28183 & 95.94 & 28.71 & 2.583 & 16.41 \\
Crustaceans & 25427 & 50.48 & 11.93 & 2.859 & 14.81 \\
Carangids & 13805 & 65.35 & 27.53 & 4.071 & 8.04 \\
Catfish & 5449 & 57.50 & -12.30 & -1.881 & 3.17 \\
Perches & 4115 & 78.00 & 29.21 & 2.508 & 2.40 \\
Silverbellies & 3903 & 74.57 & 0.86 & 0.125 & 2.27 \\
Flatfish & 3550 & 53.01 & 13.80 & 1.614 & 2.07 \\
Seer Fish & 3463 & 42.01 & -7.24 & -1.919 & 2.02 \\
Ribbonfish & 3234 & 83.54 & 29.80 & 2.522 & 1.88 \\
Tunnies & 3187 & 50.19 & 9.38 & 1.673 & 1.86 \\
Croakers & 3081 & 35.39 & 7.46 & 1.756 & 1.79 \\
Elasmobranchs & 2622 & 46.09 & -10.20 & -3.218 & 1.53 \\
Pomfrets & 1873 & 33.65 & 7.71 & 1.283 & 1.09 \\
Molluscs & 1389 & 75.15 & 36.59 & 3.403 & 0.81 \\
Lizardfish & 1292 & 72.97 & 24.45 & 2.878 & 0.75 \\
Whitefish & 1226 & 52.99 & 9.46 & 1.887 & 0.71 \\
Barracudas & 216 & 94.78 & 31.37 & 2.527 & 0.13 \\
HB \& FB & 192 & 37.69 & 5.69 & 1.191 & 0.11 \\
\hline
\end{tabular}


All the landings except mackerel improved during the decade. The decade witnessed improvement in the demersal landings of the major groups. Even though the catch decreased, mackerel remained the second largest contributor (16.41\%) to state's total landings, which is next to clupeids (35.13\%). The combined contribution of these two groups to the state's landing once again decreased by $13.04 \%$ compared to 70 's. Crustaceans showed an increasing trend in their contribution to state landings over the decades from $4.06 \%$ in 60 's to 14.81 in 80 's. Other pelagic resources such as carangids $(8.04 \%)$, seer fish $(2.02 \%)$, ribbon fish $(1.88 \%)$ and tuna $(1.86 \%)$ landings were increased. Meanwhile, demersal groups have also played significant role in increasing marine production of state during the decade. Resources like clupeids (-1.07), catfish (12.30), seer fish (-7.24), elasmobranchs $(-10.20)$ showed a negative trend in growth (CGR), even though their catch was increased.

\section{Production during 1991-2000}

Overall average marine fish landings of Karnataka decreased from $171700 \mathrm{t}$ in 19811990 to $163602 \mathrm{t}$ in 1991-2000 (Table 9). Important commercial groups such as clupeids, tunnies, seerfish, silverbellies, elasmobranchs, catfish and whitefish landings decreased during the decade. Clupeids lost their first position to mackerels in contribtion to state. Mean catch of crustaceans, carangids, croakers and pomfrets increased during the decade but showed a negative trend in growth, which was -4.53, $6.92,-3.90$ and -8.85 respectively. In addition, elasmobranchs and catfish too showed a negative trend in growth of -2.19 and -8.45 respectively. Inter year growth rate for resources such as crustaceans, perches, croakers, seer fish, pomfrets and barracudas showed significant difference during the decade (Table 9). Variations in landings (CV) were less in majority of groups compared to earlier decades.

Table 9. Mean fish catch (tons), CV, CGR and percent contribution of various major fish groups in Karnataka state during 1991-2000

\begin{tabular}{l|c|c|c|c|c}
\hline Species & Mean catch (t) & C.V & CGR & t value & \% catch to total state landings \\
\hline Mackerel & 31914 & 37.45 & 4.24 & 0.901 & 19.51 \\
Clupeids & 31419 & 21.32 & 2.16 & 0.799 & 19.20 \\
Crustaceans & 27130 & 20.93 & -4.53 & -2.499 & 16.58 \\
Carangids & 18229 & 35.31 & -6.92 & -2.107 & 11.14 \\
Perches & 13348 & 51.92 & 22.19 & 7.866 & 8.16 \\
Flatfish & 8529 & 48.45 & 1.99 & 0.383 & 5.21 \\
Molluscs & 7588 & 35.56 & 11.53 & 2.19 & 4.64 \\
Ribbonfish & 5029 & 60.00 & 5.70 & 0.82 & 3.07 \\
Croakers & 3861 & 15.99 & -3.90 & -2.907 & 2.36 \\
Tunnies & 2511 & 80.77 & 6.73 & 0.612 & 1.53 \\
Lizardfish & 2439 & 39.40 & 12.04 & 2.186 & 1.49 \\
Seer Fish & 2266 & 37.26 & 8.88 & 3.612 & 1.39 \\
Pomfrets & 2096 & 37.49 & -8.85 & -3.292 & 1.28 \\
Silverbellies & 1871 & 23.35 & 2.22 & 0.821 & 1.14 \\
Elasmobranchs & 1267 & 26.97 & -2.19 & -0.688 & 0.77 \\
Whitefish & 1058 & 32.58 & 2.75 & 0.667 & 0.65 \\
Barracudas & 1027 & 52.85 & 18.61 & 3.116 & 0.63 \\
Catfish & 291 & 93.37 & -8.45 & -1.033 & 0.18 \\
HB \& FB & 246 & 31.19 & 0.91 & 0.222 & 0.15 \\
\hline
\end{tabular}




\section{Production during 2001-2010}

Karnataka's total average marine fish production drastically increased from $163602 \mathrm{t}$ during 1991-2000 to $253608 \mathrm{t}$ in 2001-2010. Resources such as clupeids, perches, crustaceans, ribbonfishes, lizard and seerfish showed a drastic increase in their landings (Table 10). Meanwhile, mackerel, carangids, flatfishes, tunnies, pomfrets, elasmobranchs and catfish landings decreased compared to previous decades.

Table 10. Mean fish catch (tons), CV, CGR and percent contribution of various major fish groups in Karnataka state during 2001-2010

\begin{tabular}{l|c|c|c|c|c}
\hline Species & Mean catch $(\mathrm{t})$ & C.V & CGR & t value & $\begin{array}{c}\text { \% catch to total state } \\
\text { landings }\end{array}$ \\
\hline Clupeids & 75547 & 27.60 & 8.16 & 3.959 & 29.79 \\
Perches & 33079 & 25.15 & 4.84 & 1.783 & 13.04 \\
Crustaceans & 30148 & 20.32 & 0.19 & 0.08 & 11.89 \\
Mackerel & 29936 & 55.94 & 16.15 & 4.409 & 11.80 \\
Ribbonfish & 14761 & 49.09 & 13.55 & 2.456 & 5.82 \\
Carangids & 1411 & 30.89 & 4.33 & 1.106 & 5.56 \\
Molluscs & 13882 & 44.53 & 13.50 & 3.469 & 5.47 \\
Flatfish & 7871 & 26.46 & -2.10 & -0.692 & 3.10 \\
Lizardfish & 7834 & 77.60 & 27.39 & 4.328 & 3.09 \\
Seer Fish & 4610 & 21.62 & 3.25 & 1.157 & 1.82 \\
Silverbellies & 3971 & 25.25 & 1.57 & 0.509 & 1.57 \\
Croakers & 3911 & 32.00 & 7.40 & 2.188 & 1.54 \\
Barracudas & 2154 & 46.00 & 14.95 & 4.414 & 0.85 \\
Tunnies & 1858 & 40.37 & -9.70 & -2.186 & 0.73 \\
Whitefish & 1809 & 58.92 & 19.88 & 3.68 & 0.71 \\
Pomfrets & 1500 & 38.18 & 1.02 & 0.22 & 0.59 \\
Elasmobranchs & 1045 & 23.33 & -0.89 & -0.308 & 0.41 \\
Catfish & 875 & 104.92 & 23.09 & 1.889 & 0.34 \\
HB \& FB & 261 & 26.58 & -1.43 & -0.418 & 0.10 \\
\hline
\end{tabular}

During 1960's, clupeids and mackerel together formed around $75.82 \%$ of the state total catch. But in 2001-2010, clupeids, perchs, crustaceans, mackerel, ribbonfish, carangids and mollusks together formed about $83.37 \%$ of the State's total catch. This clearly shows how species composition changed over a period of time. Four resources such as flatfish (-2.10), tunnies (-9.70), elasmobranchs (-0.89) and half beak \& full beaks $(-1.43)$ showed a negative trend in growth as indicated by CGR. About seven resources such as clupeids (8.16), mackerel (16.15), ribbon fish (13.55), molluscs (13.50), lizardfish (27.39), barracudas (14.95) and whitefish (19.88) showed significant difference in inter year growth rate and their CGR was very high.

\section{Present status of stock}

While attempting to classify 19 resource groups following the method suggested by Mohamed et al., (2010), it was found that 8 resource groups fall under 'abundant', 4 groups under 'less abundant' and 7 groups under 'declining' class (Table 11). About 9 groups of 19 attained maximum historical landings during the decade 2001-2010, 3 groups during in 1991-2000, 6 groups in 1981-1990 and one group during 1961-1970.

The percentage contribution of these classified stocks to Karnataka's total average marine landings from 2008-2010 and 2001-2010 are shown in Table 12. Abundant class 
contributed around $56.32 \%$ in $2001-10$ and $57.43 \%$ in $2008-10$ respectively. Less abundant group contributed around $23.38 \%$ in $2001-10$ and $19.66 \%$ in $2008-10$ where as declining class contributed around $18.55 \%$ in $2001-10$ and $19.66 \%$ in $2008-10$ to the average catch of Karnataka. Out of 19 groups in the present study, none of the resource fall under depleted and collapsed class.

Table 11. Classification of different resource groups based on last three years (2008-10) average landings

\begin{tabular}{l|l|l|l|l|l|l}
\hline Resources & $\begin{array}{l}\text { Average } \\
\text { landings } \\
\text { (t) during } \\
2008-10\end{array}$ & $\begin{array}{l}\text { Maximum } \\
\text { annual } \\
\text { landing } \\
\text { during } \\
1961-2010\end{array}$ & Year & $\begin{array}{l}\text { Percentage } \\
\text { of total } \\
\text { landings }\end{array}$ & $\begin{array}{l}\text { Stock status of } \\
\text { Karnataka }\end{array}$ & $\begin{array}{l}\text { Stock status of } \\
\text { India as per } \\
\text { Sathianandan et } \\
\text { al., }\end{array}$ \\
\hline Clupeids & 93543 & 110253 & 2007 & 84.84 & Abundant & Abundant \\
Seer fish & 5210 & 6826 & 1982 & 76.33 & Abundant & Abundant \\
Whitefish & 3134 & 3668 & 2010 & 85.45 & Abundant & Declining \\
Barracudas & 3373 & 4150 & 2010 & 81.28 & Abundant & Abundant \\
Perches & 43473 & 49151 & 2008 & 88.45 & Abundant & Abundant \\
Croakers & 5341 & 6542 & 2010 & 81.64 & Abundant & Abundant \\
Lizard fish & 16845 & 17312 & 2008 & 97.30 & Abundant & Abundant \\
Molluscs & 20787 & 25440 & 2010 & 81.71 & Abundant & Abundant \\
Carangids & 18457 & 29668 & 1991 & 62.21 & Less abundant & Abundant \\
Ribbonfish & 18305 & 28744 & 2006 & 63.68 & Less abundant & Less abundant \\
HB \& FB & 251 & 363 & 2008 & 69.24 & Less abundant & Abundant \\
Crustaceans & 28601 & 57112 & 1987 & 50.08 & Less abundant & Abundant \\
Mackerel & 47203 & 101790 & 1989 & 46.37 & Declining & Abundant \\
Tunnies & 1484 & 7365 & 1992 & 20.14 & Declining & Abundant \\
Silverbellies & 4200 & 11563 & 1986 & 36.32 & Declining & Abundant \\
Pomfrets & 1763 & 3902 & 1968 & 45.17 & Declining & Abundant \\
Catfish & 1860 & 10253 & 1982 & 18.14 & Declining & Abundant \\
Flatfish & 7968 & 18185 & 1992 & 43.82 & Declining & Less abundant \\
Elasmobranchs & 1166 & 5058 & 1982 & 23.06 & Declining & Less abundant \\
\hline
\end{tabular}

Table 12. Stock contribution to mean catch of Karnataka during different years

\begin{tabular}{l|c|c}
\hline Stock contribution & $\begin{array}{l}\text { Percentage contribution to average catch } \\
\text { from 2001-10 }\end{array}$ & $\begin{array}{l}\text { Percentage contribution to the } \\
\text { average catch from 2008-2010 }\end{array}$ \\
\hline Abundant & 56.32 & 57.43 \\
Less abundant & 23.38 & 19.66 \\
Declining & 18.55 & 19.66 \\
\hline
\end{tabular}

About 13 groups showed highest mean catch during 2001-2010 and 3 groups during the decade 1980's and 1990's (Figure 2). None of the resources showed any highest mean catch during the decade 1960's and 70's. Decadal change in compound growth rate with respect to number of groups (resources) is shown in Figure 3. Out of 19, 15 groups showed positive CGR during 60's \& 2000, 14 during 80's and 13 during 70's \& 90's. A negative CGR was shown by 6 groups in 70's \& 90's, 5 groups in 80 's and 4 groups in 60's \& 2000. Mean coefficient of variation during different decades indicates that the variation in landings during earlier decades were higher compared to recent decades (Figure 4). 


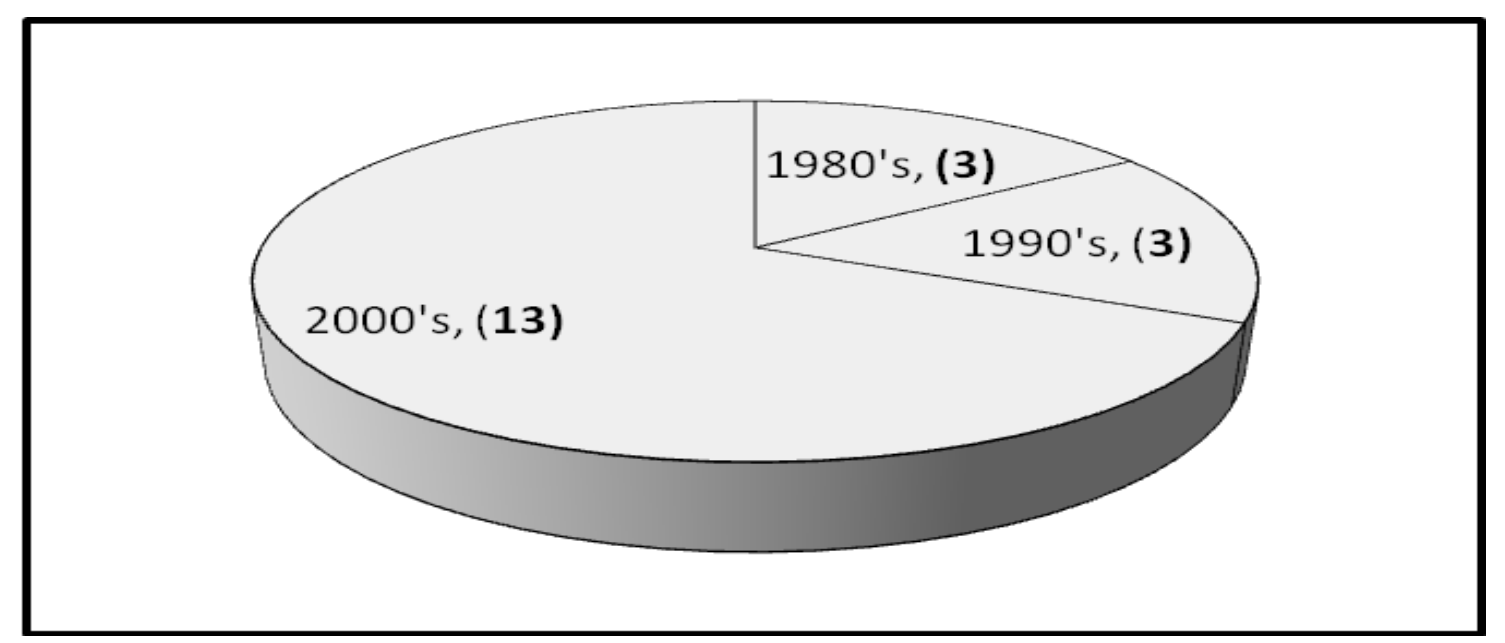

Figure 2. Number of groups showing the highest mean catch during the different decades

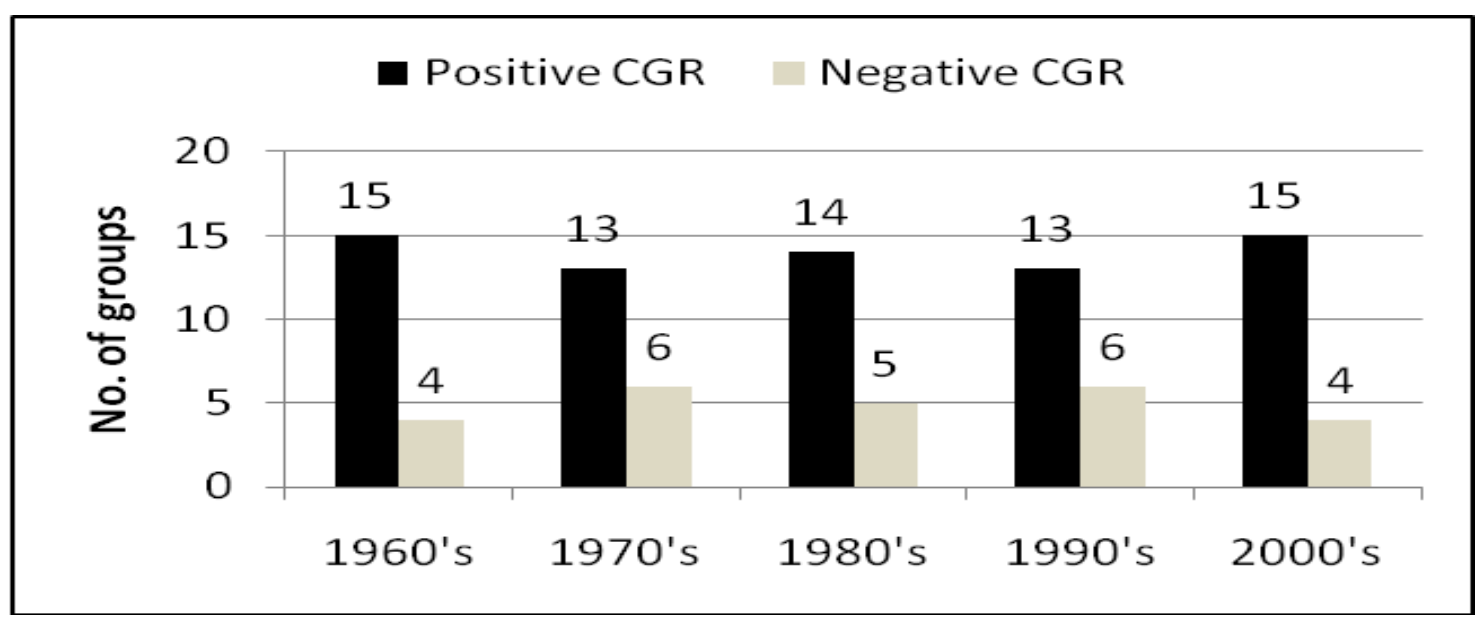

Figure 3. Decadal changes in CGR with respect to number of groups

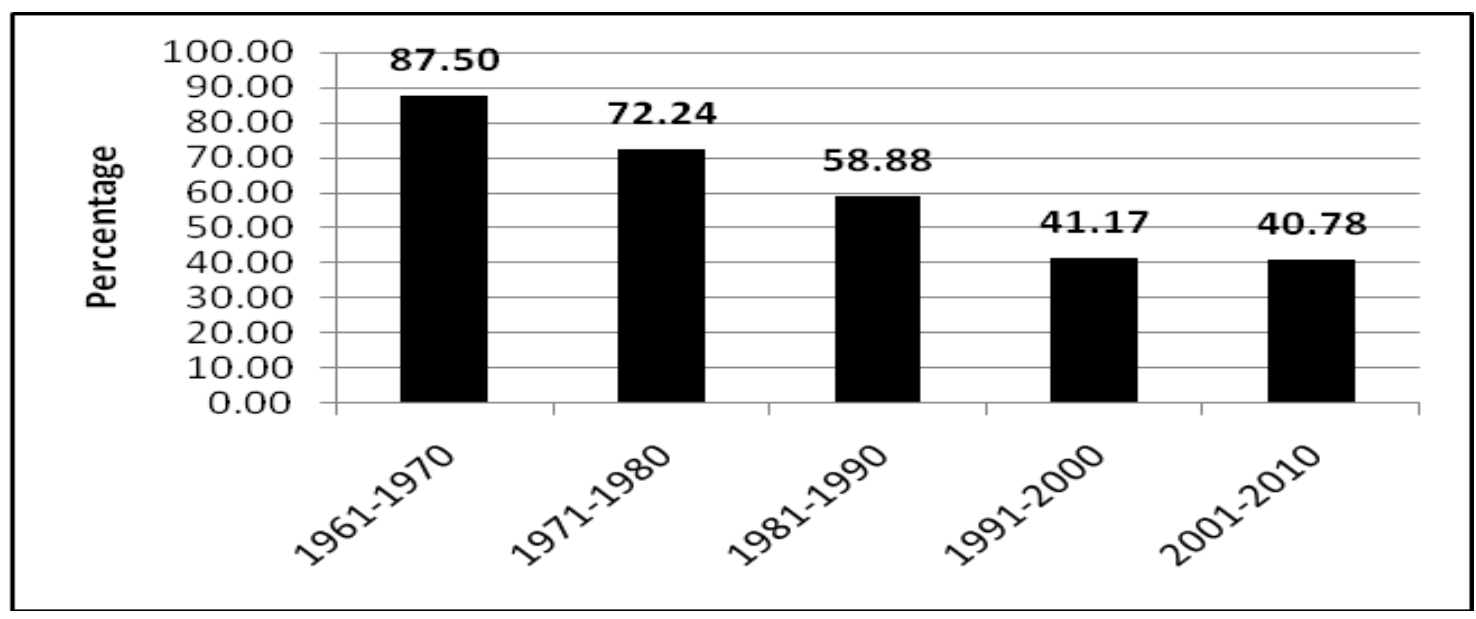

Figure 4. Mean Coefficient of Variation during different decades 


\section{Discussion}

During the last five decades there had been structural and qualitative changes in marine fisheries along the Karnataka coast and showed an increase in mean catch except during 1990's. Out of 19 groups identified for study, pelagic resources dominate the fishery of state from 1961-2010. Pelagic fishery was characterized by the dominance of sardine and mackerel during the early decades. The exploitation of major marine fisheries resources during 60's was mainly by traditional fishing gears such as Rampani, small shore-seine, boat seine, gill net, drift net, cast net and hook and line. Rampani was the major gear, contributing around $60 \%$ of marine fish production. In 1966, a scheme for construction and distribution of trawlers was introduced in the state and modernization of fisheries took place during following decades which resulted in increased contribution of demersal resources. Introduction of more efficient gears, especially purse seines resulted in an increased pelagic catch during 70's and 1980's (Mohamed et al., 1998). Meanwhile, Rampani started disappearing during the 1970's, and mechanized crafts and gears started dominating the fishery. The contribution of pelagic groups to state's average total landings decreased because of increased contribution of demersal groups. The demersal landings improved from the 1980's onwards, especially with molluscs, flatfish and perches which were mainly caught by increased operation of multiday trawlers (Mohamed et al., 1998). Motorization of country crafts during mid 80's resulted in introduction of ring seine (Panikkar and Sathiadas, 1993) which led to the increased landings during 1981-1990. Increase in trawl production during 1990's was due to the adoption of high opening trawls and multiday trawls. Increased fishing efforts by mechanized fishing during 1991-2000 resulted in decreased landings of major resources like clupeids, seerfish, tunnies, catfish, elasmobranchs, silverbellies and whitefish which lead to decrease in the state's average catch. The modernization of fishing fleets and uncontrolled expansion of fishing efforts are the main reasons for declining growth rates of total marine fish production (Bhat and Bhatta, 2001). Major pelagic resources decreased mainly because of the reduction in purse seine catch. Though the average landings for state decreased during 1990's crustaceans and molluscs catch increased over the decades. Mechanized trawlers have increased the exploitation of prawns' resources since the beginning of the 1970's due to increasing demand of prawns for export (Sukumaran, 1985).

Cephalopod resources gained significance after 1985 and production increased substantially due to demand in foreign trade. Increased number of fishing days by multiday trawls, expansion of the fishing ground, introduction of steel trawlers resulted in increased landings of cephalopods during recent decades (Sasikumar and Mohamed., 2012).

Classification of different resource groups based on last three years' (2008-2010) average catch indicates that the state and country's situation as a whole is different. For example, whitefish stock falls under abundant group in Karnataka but are declining at national scenario. Similarly less abundant groups in Karnataka such as carangids, half beak \& full beaks, eels and crustaceans falls under abundant category at national level.

The whitefish stock status has considerably improved recently and noted abundant in the present study which was once under declining category (Mohamed and Zacharia.,2009). Presently, stock status of mackerel, tuna and elasmobranchs are declining, while clupeids and seerfish fall under abundant group. According to Mohamed and Zacharia (2009) important resources such as mackerel, sardine, seerfish, tunas, shark, skates and rays decline in their catch within five years due to increase in fishing effort. This indicates that the stocks might have recovered during recent years 
especially during 2007 to 2010. Increased fishing effort by multiday trawlers, introduction of purse seines in 1980s and pollution have been responsible for declining growth rates during 90's.

Despite contributing $9.26 \%$ to the total marine fish landings of India in the recent decade (2001-2010), the marine fishery of Karnataka is still successfully sustaining its fishery resources. Also, growth rates of important resources (15 groups) have shown a positive trend. The study shows how the state wise scenario is different from national scenario and state wise understanding of marine fishery resources is very important to formulate the regulation and management measures.

Acknowledgements. The authors would like to thank Dr. W.S. Lakra, Director, Central Institute of Fisheries Education, Mumbai, India for all his support. We also extend our gratitude to Central Marine Fisheries Research Institute for providing data for the present study. This study was carried out with financial support from the Central Institute of Fisheries Education (Indian Council of Agricultural Research), India.

\section{REFERENCES}

[1] Bhatta, R., Rao, K. A., Nayak, S. K. (2003): Marine fish production in Karnataka: Trends and composition. - Economic and Political Weekly 38:4685-4693.

[2] Bhat, M. G., Bhatta, R. (2001): An economic analysis of sustainability of marine fish production in Karnataka. Project Report 1999-2001, Environmental Economics Research Committee Indira Gandhi Institute of Development Research, Mumbai.

[3] Bundy, A., Pauly, D. (2001): Selective harvesting by small-scale fisheries: Ecosystem analysis of San Miguel Bay, Philippines. - Fisheries Research 53(3): 263-281.

[4] Caddy, J. F., Csirke, J., Garcia, S. M., Grainger, R. J. R. (1998): How pervasive is" fishing down marine food webs"? - Science 282:1383-1383.

[5] Casey, J. M., Myers, R. A. (1998): Near extinction of a large widely distributed fish. Science 281: 690-2.

[6] CMFRI. (2010): Marine Fisheries Census (2010), Part 7, Karnataka, Govt. of India, Ministry of Agriculture, Dept. of Animal Husbandry, Dairying \& Fisheries and Central Marine Fisheries Research Institute, Indian Council of Agricultural Research, New Delhi.

[7] CMFRI. (2012): Annual report 2011-12. Central Marine Fisheries Research Institute, Cochin, 186 pp.

[8] Dehadari, P. V.,Yadava, Y. S. (2004): Fisheries Development. Vol.13. - In: State of the Indian Farmer-A Millennium Study. Publ. by Dept. of Agriculture and Cooperation, Ministry of Agriculture, Govt. of India, New Delhi, 173 pp.

[9] Eagle, J., Thompson, Jr B. H. (2003): Answering Lord Perry's question: dissecting regulatory overfishing. - Ocean \& coastal management 46: 649-679.

[10] FAO. (2014): The State of World Fisheries and Aquaculture 2014. Food and Agriculture Organization, Rome, 223 pp.

[11] Government of India- GoI. (2012): Annual Report 2011-2012. Department of Animal Husbandry, Dairying \& Fisheries, Ministry of Agriculture. 104pp.

[12] Jackson, J. B. C., Kirby, M. X., Berger, W. H., Bjorndal, K. A., Botsford, L. W., Bourque, B. J., Bradbury, R. H., Cooke, R., Erlandson, J., Estes, J. A., Hughes, T. P., Kidwell, S., Lange, C. B., Lenihan, H. S., Pandolfi, J. M., Peterson, C. H., Steneck, R. S., Tegner, M. J., Warner, R. R. (2001): Historical overfishing and the recent collapse of coastal ecosystems. - Science 293:629-637.

[13] Jensen, C. L. (2002): Reduction of the fishing capacity in "common pool" fisheries. Marine Policy 26:155-158. 
[14] Kuriakose, S., Mini, K. G. (2006): A stochastic model to analyse pelagic fishery resource dominance along the Karnataka coast (west coast of India). - Indian Journal of Marine Sciences 35:257-262.

[15] Mayers, R. A.,Worm, B. (2003): Rapid worldwide depletion of predatory fish 354 communities. - Nature 423(6937):280-283.

[16] McManus, J. W., Reyes, R .B. Jr., Nañola, C. L. Jr. (1997): Effects of some destructive fishing methods on coral cover and potential rates of recovery. - Environmental Management 21: 69-78.

[17] Mohamed, K. S., Zacharia, P. U. (2009): Prediction and modelling of marine fishery yields from the Arabian Sea off Karnataka using Ecosim. - Indian Journal of Marine Fisheries 38: 69-76.

[18] Mohamed, K. S., Muthiah, C., Zacharia, P. U., Sukumaran, K. K., Rohit, P., Krishnakumar, P. K. (1998): Marine Fisheries of Karnataka State, India. Naga, The ICLARM Quarterly 21: 10-15.

[19] Mohamed, K. S., Sathianandan, T. V., Zacharia, P. U., Asokan, P. K., Krishnakumar, P. K., Abdurahiman, K. P., Shettigar, V., Durgekar N. R. (2010): Depleted and Collapsed Marine Fish Stocks along Southwest Coast of India - A Simple Criterion to Assess the Status. - In: B. Meenakumari., M. R. Boopendranath., L. Edwin., T. V. Sankar., N. Gopal \& G. Ninan (eds) Coastal Fishery Resources of India; Conservation and Sustainable Utilisation. Society of Fisheries Technologists, Cochin, pp 67-76.

[20] Panikkar, K. K. P., Sathiadhas, R (1993) Structural change in Karnataka marine fishery and its socio-economic implications. Marine Fisheries Information Service, Technical and Extension Series, 121. pp. 1-5.

[21] Pauly, D., Christensen, V., Dlasgaard, J., Froese, R., Torres, F. Jr. (1998): Fishing down marine food webs. - Science 279: 860-863.

[22] Pauly, D., Christensen, V., Guénette, S., Pitcher, T. J., Sumaila, U. R., Walters, C. J., Watson, R., Zeller, D. (2002): Towards sustainability in world fisheries. - Nature 418: 689-695.

[23] Sasikumar, G., Mohamed, K. S. (2012): Temporal patterns in cephalopod catches and application of non-equilibrium production model to the cephalopod fishery of Karnataka. - Indian Journal of Geo-Marine Sciences 41: 134-140.

[24] Sathianandan, T. V., Jayasankar, J., Kuriakose, S., Mini, K. G., Mathew, W. T. (2011): Indian marine fishery resources: optimistic present, challenging future. - Indian Journal of Fisheries 58: 1-15.

[25] Shyam, S. S., Sathiadhas, R., Sathianandan, T. V., Geetha, R., Aswathy, N., Vipinkumar, V. P. (2010): Marine fisheries resources: exploitation, management and regulations in India. - Seafood Export Journal 40: 25-34.

[26] Sukumaran, K. K. (1985): Night Trawling for Prawns at Mangalore encouraging. Marine Fisheries Information Service, Technical and Extension Series 65, 7-12.

[27] Zeller, D., Pauly, D. (2005): Good news, bad news: global fisheries discards are declining, but so are total catches. - Fish and Fisheries 6:156-159. 